\title{
Influence of mutations affecting gonadotropin production or responsiveness on expression of inhibin subunit mRNA and protein in the mouse ovary
}

\author{
Rachel C Hirst, Margaret H Abel, Vivienne Wilkins, Christine Simpson, Phil G Knight ${ }^{1}$, \\ Fu-Ping Zhang ${ }^{2}$, Ilpo Huhtaniemi ${ }^{2,3}$, T Rajendra Kumar ${ }^{4}$ and Harry M Charlton
}

Departments of Human Anatomy and Genetics, University of Oxford, Oxford OX1 3QX, UK, ${ }^{1}$ School of Animal and Microbial Sciences, University of Reading, Reading RG6 6AJ, UK, ${ }^{2}$ Department of Physiology, Institute of Biomedicine, University of Turku 20502 Turku, Finland, ${ }^{3}$ Institute of Reproductive and Developmental Biology, Imperial College London, Du Cane Road, London W12 ONN, UK and ${ }^{4}$ Department of Pathology and Molecular and Cellular Biology, Baylor College of Medicine, Houston, Texas 77030, USA

Correspondence should be addressed to R C Hirst; Email: rachel.hirst@anat.ox.ac.uk

\begin{abstract}
Measurement of inhibins A and B in the serum of normal cyclic rodents has implicated FSH in the regulation of these peptides within the ovary. To extend these observations we have used a panel of mutant mice carrying mutations which affect either the production of, or the ability to respond to, FSH and LH. As a consequence, the females are infertile and show different degrees of follicular development. The aim of this study was to measure inhibin gene transcription in the ovaries of these mutant females together with inhibin protein levels in ovaries and serum and to relate these to follicular development within the ovary. Comparison was made with a pool of normal/heterozygous females. In hpg females where lack of GnRH production results in the absence of gonadotropin synthesis, in $\mathrm{FSH} \beta$ knockout (FSH $\beta K O$ ) females where disruption of the gene encoding $\mathrm{FSH} \beta$ results in the absence of FSH production, and in FSH receptor knockout (FSHRKO) females which are unable to respond to circulating $\mathrm{FSH}$, follicular development remains at the pre-antral stage in these three mutants. Only in the hpg females were common inhibin $\alpha$ subunit mRNA levels significantly lower than normal. In these three mutants, however, mRNA levels for both the $\beta A$ and $\beta B$ subunits were extremely low compared with normal mice. At the protein level, neither inhibin A nor $B$ was detected in the serum of these three mutants; however inhibin $B$, albeit at very low levels, was detectable within the ovaries. These observations confirm a major role for FSH in the control of transcription of the $\beta$ A and $\beta B$ genes but suggest that the constitutive transcription of the alpha subunit is less dependent on FSH. In contrast, in LH receptor knockout (LuRKO) female mice inhibin $\beta A$ subunit mRNA levels were similar to those measured in normal/heterozygous females but levels of inhibin $\alpha$ and $\beta B$ subunit mRNAs were significantly higher than in the normal group. This was reflected in significantly higher inhibin B protein levels in ovaries and serum. An inability to respond to LH combined with high circulating levels of FSH leads to a high proportion of antral follicles in LuRKO females, with granulosa cells constituting the major cell type within the ovary. The high percentage of antral granulosa cells is likely to account for the significantly higher levels of inhibin B production in these ovaries.

Reproduction (2004) 128 43-52
\end{abstract}

\section{Introduction}

Inhibin consists of an $\alpha$ subunit linked to one of two $\beta$ subunits, $\beta A$ or $\beta B$, to form either inhibin $A$ or inhibin B. All three subunits are encoded by separate genes (Mason et al. 1985, Forage et al. 1986, Mayo et al. 1986). The name inhibin derives from the early observation that an aqueous testis extract could inhibit the appearance of 'castration cells' in gonadectomized rats. It was subsequently shown that injections of follicular fluid could suppress pituitary follicle-stimulating hormone (FSH) secretion in rats (De Jong \& Sharpe 1976, Schwartz \& Channing 1977) and in 1985 inhibin was finally isolated from porcine and bovine follicular fluid (Ling et al. 1985, Robertson et al. 1985).

In the female, inhibin has both endocrine and local actions within the ovary (Findlay 1994). Ovariectomy on any day of the rat estrous cycle induced a marked rise in serum FSH (D'Agostino et al. 1989, Ackland et al. 1990) 
while long-term castration resulted in undetectable levels of inhibins in serum consistent with a gonadal origin for these hormones (Woodruff et al. 1996). Administration of recombinant inhibin to both female and male rats results in a decrease in circulating levels of FSH (Rivier et al. 1991, Woodruff et al. 1993), while in vitro FSH and estradiol independently increase inhibin production by rat granulosa cells in culture. In addition, inhibin A has been shown to stimulate luteinizing hormone (LH)-induced androgen production by rat (Hsueh et al. 1987), human (Hillier et al. 1991) and bovine (Wrathall \& Knight 1995) thecal cells in culture. The development of assays which detect only dimeric forms of inhibin and discriminate between isoforms (Muttukrishna et al. 1994, Groome et al. 1996) has allowed the measurement of the biologically active inhibin proteins in both tissue and serum. Using such assays, Woodruff et al. (1996) detected both inhibin $A$ and $B$ in the serum of female rats and showed a differential secretion of inhibin $A$ and $B$ during the period of follicular development in the rat estrous cycle, suggesting either different sources or differering regulation of these hormones during this period. To investigate further the relationship between FSH and inhibins we have used a panel of female mice carrying mutations, both natural and genetically engineered which affect gonadotropin production or responsiveness and subsequently modify ovarian follicular development. We have measured inhibin subunit mRNA levels in the ovaries of these mice using quantitative real-time PCR and attempted to correlate these with ovarian histology and ovarian and serum inhibin protein levels, together with immunohistochemical localization of the inhibin subunit proteins within the ovaries.

\section{Materials and Methods}

\section{Animals}

All mice used in this study were bred in the Department of Human Anatomy and Genetics, University of Oxford and maintained as required under United Kingdom Home Office regulations. All animal procedures were carried out under Home Office licence. The following strains of mice were used: hypogonadal ( $h p g$ ) mice, with a deletion in the gene encoding gonadotropin releasing hormone $(\mathrm{GnRH})$ (Cattanach et al. 1977, Mason et al. 1986), and three strains of mice with genetic disruption of specific genes: $\mathrm{FSH} \beta$ knockout ( $\mathrm{FSH} \beta K \mathrm{~K})$ mice with a deletion in the gene encoding the FSH $\beta$ subunit (Kumar et al. 1997), FSH receptor knockout (FSHRKO) mice with a deletion in the gene encoding the FSH receptor (Abel et al. 2000) and luteinizing hormone receptor knockout (LuRKO) mice with a deletion in the luteinizing hormone $(\mathrm{LH})$ receptor gene (Zhang et al. 2001). The hpg mice were on a $\mathrm{C} 3 \mathrm{H} / \mathrm{HeH}-101 / \mathrm{H}$ genetic background and the knockout mice on a mixed C57B16/129 background. All mice used were 8 weeks of age.

\section{Analysis of mutant mice}

Mutations were identified by PCR analysis of tail DNA as previously described for hpg (Lang 1991) and LuRKO (Zhang et al. 2001) mice. For the FSHRKO mice the following primer pairs were used: forward GACTGATGCAGGCCACCATT, reverse GCGTTCACCAGTCATGCGTA, and neo forward TGGCTACCCGTGATATTGCT; for the FSH $\beta$ colony, primers within exon 3 were used to separate heterozygous from knockout mice: forward GATCTGGTGTATAAGGACCC and reverse CACGGTGCAGTCAGTGCTGT.

\section{Tissue and serum collection}

All procedures were carried out under anesthesia (Rompun:Ketaset: $0.1 \mathrm{ml} / \mathrm{kg}$ of a $20 \%: 4 \%(\mathrm{v} / \mathrm{v})$ solution; Veterinary Supplies, University of Oxford, Oxon, UK). Ovaries were dissected out, weighed and snap frozen in liquid nitrogen and stored at $-70^{\circ} \mathrm{C}$. One ovary was used to extract RNA and the other to measure inhibin content. Blood was collected from the jugular sinus and serum was separated and frozen at $-20^{\circ} \mathrm{C}$ for assay. Ovaries taken from a further set of mice were collected for histological examination and immunohistochemistry.

\section{Ovary extracts for inhibin assays}

To prepare extracts for inhibin assay ovaries were placed in microfuge tubes containing $300 \mu$ l phosphate-buffered saline $(\mathrm{pH} 7.3)$ containing $1 \%$ BSA and sonicated for $10-$ $15 \mathrm{~s}$ using an ultrasonic tissue disintegrator (probe amplitude setting $8 \mu \mathrm{m}$ peak to peak; MSE Instruments). After freezing and thawing homogenates were centrifuged for $5 \mathrm{~min}$ at $14000 \times \mathbf{g}$ and supernatants were assayed without further dilution.

\section{Hormone assays}

Serum and gonadal inhibin A concentrations were measured using a previously reported two-site enzymelinked immunosorbent assay (Muttukrishna et al. 1994). The detection limit was $2 \mathrm{pg}$ recombinant human inhibin $\mathrm{A} / \mathrm{ml}$ and within- and between-plate coefficients of variation were $3.5 \%$ and $9.2 \%$ respectively. Inhibin B was measured using a previously described two-site enzymelinked immunosorbent assay (Groome et al. 1996) with a sensitivity of $30 \mathrm{pg}$ recombinant inhibin $\mathrm{B} / \mathrm{ml}$ and intra- and interassay coefficients of variation of $4.2 \%$ and $9.8 \%$ respectively. Mouse serum and ovary extract samples gave dilution curves in the inhibin $A$ and $B$ assays that were parallel to the recombinant human inhibin standards used.

\section{Histology}

For histological examination, ovaries and uteri were fixed overnight in Bouin's solution, embedded in wax, and $10-\mu \mathrm{m}$ sections were stained with hematoxylin and eosin. 


\section{Immunohistochemistry}

Ovaries were fixed overnight in Bouin's solution before embedding in Paraplast embedding medium. Sections $(10 \mu \mathrm{m})$ were cut onto vectabond-treated slides, paraffin removed with xylene, followed by descending concentrations of ethanol. Sections were rehydrated and permeabilized with Tris-buffered saline $(\mathrm{pH}$ 7.4) containing $0.05 \%$ Triton X-100 for 15 min, blocked with $3 \% \mathrm{H}_{2} \mathrm{O}_{2}$ for $10 \mathrm{~min}$ followed by Mouse on Mouse (M.O.M.) blocking reagent (Vector Laboratories, Peterborough, Cambridgeshire, UK) for $60 \mathrm{~min}$. Sections were incubated in M.O.M. diluent for $5 \mathrm{~min}$ followed by incubation with the primary mouse monoclonal antibodies (neat supernatant): anti-human inhibin alpha subunit, anti-human inhibin beta $B$ subunit and anti-human inhibin beta A (Bio-Oxford Innovation Ltd; Heyford Park, Oxon, UK) for $60 \mathrm{~min}$.

Secondary antibody M.O.M. biotinylated anti-mouse IgG was applied for $10 \mathrm{~min}$, followed by Vectastain $A B C$ reagent for $5 \mathrm{~min}$. Sections were then incubated in a 3,3'diaminobenzidine (DAB) liquid substrate system (Sigma D7679) and counterstained with hematoxylin. Controls were performed in parallel. First, omission of the primary antibody incubation step, followed by subsequent secondary antibody and DAB incubations. Secondly, primary antibody incubation but omission of the secondary antibody incubation step. Positive specific staining was only detected in the situation where we had primary antibody followed by secondary antibody followed by DAB.

\section{RNA extraction and CDNA synthesis}

Total RNA was extracted with Trizol (Life Technologies, Paisley, Strathclyde, UK) and residual genomic DNA was removed by DNAse treatment (DNA-free, Ambion Inc supplied by AMS Biotechnology, Abingdon, Oxon, UK). DNAse-treated RNA was quantified by spectrophotometric measurement at $\lambda 260 \mathrm{~nm}$. One microgram RNA was reverse transcribed using Random decamers (Ambion) and Moloney murine leukemia virus reverse transcriptase (Life Technologies).

\section{Measurement of inhibin mRNA levels}

Quantitative real-time PCR (for a review see Bustin 2002), using the $\mathrm{ABI} 7700$ was used to follow the gene expression of inhibin $\alpha, \beta A$ and $\beta B$ subunits.

To measure cDNA levels a threshold cycle $(\mathrm{Ct})$ was selected within the exponential phase of the amplification for all standards and samples. Arbitrary standards were generated by serial dilutions of a cDNA pool from normal mouse ovaries (representative of all stages of the estrous cycle). A standard curve was generated by plotting standards against $\mathrm{Ct}$ values, and sample values were read from this standard curve (Fig. 1).

In the present study, mRNA levels were normalized relative to an endogenous control $18 \mathrm{~S}$ ribosomal RNA, to allow comparison of different mRNAs between tissues. Two potential normalizers were investigated in addition to 18S RNA-glyceraldehyde 3-phosphate dehydrogenase (G3PDH) and Williams-Beuren syndrome chromosome region 1 (Wbscr1) gene; however both showed greater variation across the mutant and wild-type females compared with $18 \mathrm{~S}$.

\section{Primers and probes}

Primers and probes were designed using Primer Express (Applied Biosystems, Warrington, Cheshire, UK) and are listed in Table 1. Sequence information for each of the inhibin subunits was obtained by submission of the respective accession numbers to GenBank.

Real-time PCR experiments were carried out in a $25 \mu \mathrm{l}$ volume using a 96-well plate format. Universal Taqman

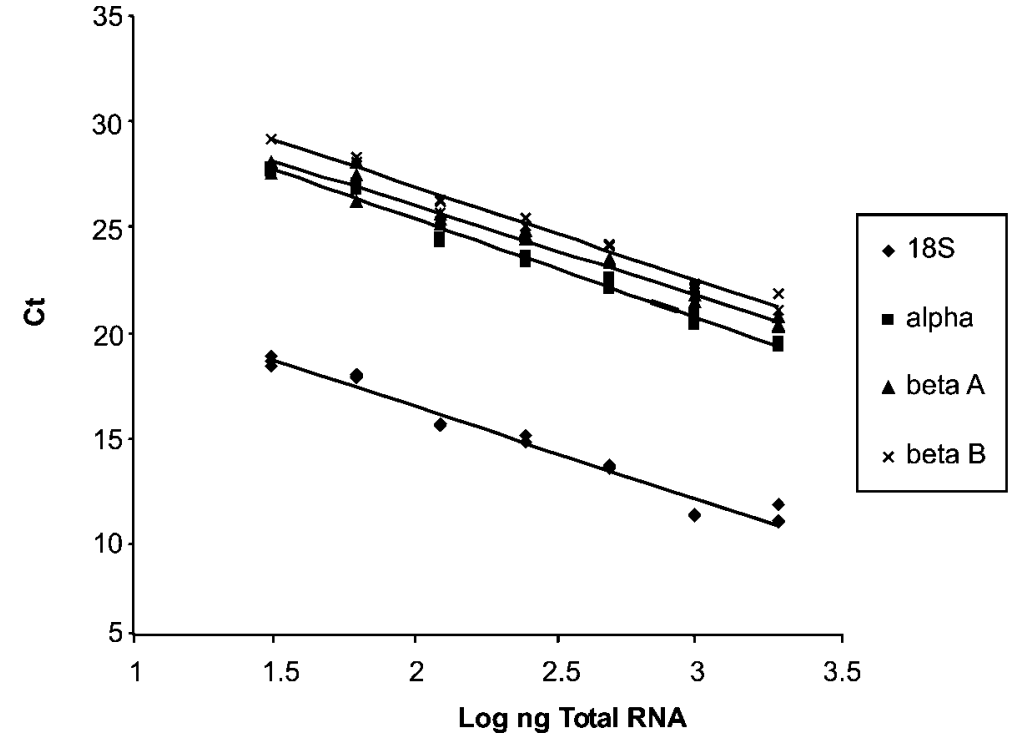

www.reproduction-online.org
Figure 1 Standard curves for $18 \mathrm{~S}$ and inhibin subunits $(\alpha, \beta A$ and $\beta B)$ prepared by serial dilutions of normal ovary cDNA (pooled from all stages of the estrous cycle). The log of the RNA concentration was plotted against the threshold cycle $(\mathrm{Ct})$ and regression analysis was used to generate the best-fit line. 
Table 1 Primer and probe sequences ( $5^{\prime}$ to $\left.3^{\prime}\right)$ for inhibin $\alpha, \beta A$ and $\beta B$ subunits.

\begin{tabular}{lll}
\hline & Primer/probe & Sequence $\left(5^{\prime}\right.$ to $\left.3^{\prime}\right)$ \\
\hline Inhibin alpha (X55957) & Forward & AAGATGTCTCCCAGGCTATCCTT \\
& Reverse & ATGGCCGGAATACATAAGTGAAG \\
& Probe & TCCCAGCTACAGGTGCCACCTGTGA \\
Inhibin beta A (X69619) & Forward & CCAAAGTCACCATCCGTCTATTT \\
& Reverse & CTCATCCCCCGTGTCAA \\
Inhibin beta B (X69620) & Probe & CAGCAGAAGCACCCACAGGGCAG \\
& Forward & GCTCATCGGCTGGAACGA \\
& Reverse & GCCCTCACAGTAGTTCCCGTAGT \\
\hline
\end{tabular}

master mix, primers and probes were purchased from Applied Biosystems. Primers were used at $300 \mathrm{nM}$ and probes at $200 \mathrm{nM}$ final concentration. Reactions were carried out and fluorescence was detected on an ABI 7700 system (Applied Biosystems). A no-RT control for each sample was screened to assess the presence of residual genomic DNA.

\section{Statistical analysis}

Differences between groups were analyzed by single-factor ANOVA, followed by Fisher's post-hoc test. Differences where $P$ values were $<0.05$ were considered statistically significant. Data for inhibin serum levels showed heterogeneity of variance and were normalized by logarithmic transformation before analysis.

\section{Results}

\section{Measurement of inhibin mRNA levels in normal and mutant ovaries (Fig. 2)}

Inhibin $\alpha$ subunit mRNA levels were significantly lower in the ovaries of hpg females compared with levels in all other groups with the exception of FSHRKO females. Levels of inhibin $\alpha$ subunit mRNA did not differ between FSH $\beta K O, F S H R K O$ and normal/heterozygous females but in the ovaries of the LuRKO females they were significantly higher than levels measured in the normal/heterozygous group $(P<0.05)$.

Inhibin $\beta A$ subunit mRNA levels were very low in the ovaries of FSH $\beta K O, F S H R K O$ and $h p g$ females and all were significantly lower than ovarian levels in LuRKO and normal/heterozygous females ( $P<0.001$ for all groups). There was no significant difference in the ovarian levels of inhibin $\beta A$ subunit between LuRKO and normal/heterozygous females.

Inhibin $\beta B$ subunit mRNA levels were also low in the ovaries of FSH $\beta K O$, FSHRKO and $h p g$ females and there were no significant differences between these groups. Significantly higher levels of inhibin $\beta B$ subunit were recorded in the ovaries of both LuRKO and normal/heterozygous females $(P<0.001)$ and mRNA levels in LuRKO ovaries were twice those recorded in normal/heterozygous females $(P<0.001)$.

\section{Ovarian and uterine histology (Fig. 3)}

The ovaries of hpg females contain numerous small follicles located around the periphery and throughout the interstitial tissue. The ovaries of the FSH $\beta$ KO and FSHRKO females show the same range of follicles, but like $h p g$ ovaries lack antral follicles. The larger ovarian size in the FSH $\beta K O$ and FSHRKO females is due to the increased amount of stromal tissue compared with the hpg ovary.

Ovaries from the LuRKO females contain antral follicles in addition to the earlier stages found in the $h p g$ and FSHKO mutants. Very little interstitial tissue is present between the follicles but a defined layer of thecal cells is seen around each follicle. In contrast, all follicular stages together with corpora lutea were identified in ovaries from the normal and heterozygous females.

Uteri from all four mutant females were thin and threadlike and as shown in cross section showed little development of the luminal epithelium. In contrast, uteri from normal and heterozygous females were much larger with well developed luminal epithelium reflecting the presence of biologically active estrogen in the serum of these females.

\section{Ovarian inhibin content (Table 2)}

\section{Inhibin A}

Levels of inhibin A were below the level of detection of the assay in the ovaries of FSH $\beta K O$, FSHRKO and $h p g$ females. In contrast, inhibin A was detected in the ovaries of both LuRKO and normal/heterozygous females. There was no significant difference in ovarian inhibin A content between these two groups.

\section{Inhibin B}

Inhibin B was detected within the ovaries of all mutants. There was no significant difference between the FSHRKO, $\mathrm{FSH} \beta \mathrm{KO}$ and hpg mice, but in these mutants the content was significantly lower than normal/heterozygous and LuRKO females $(P<0.001)$. Levels of ovarian inhibin B were significantly higher in the LuRKO females compared with the normal/heterozygous females $(P<0.001)$. 

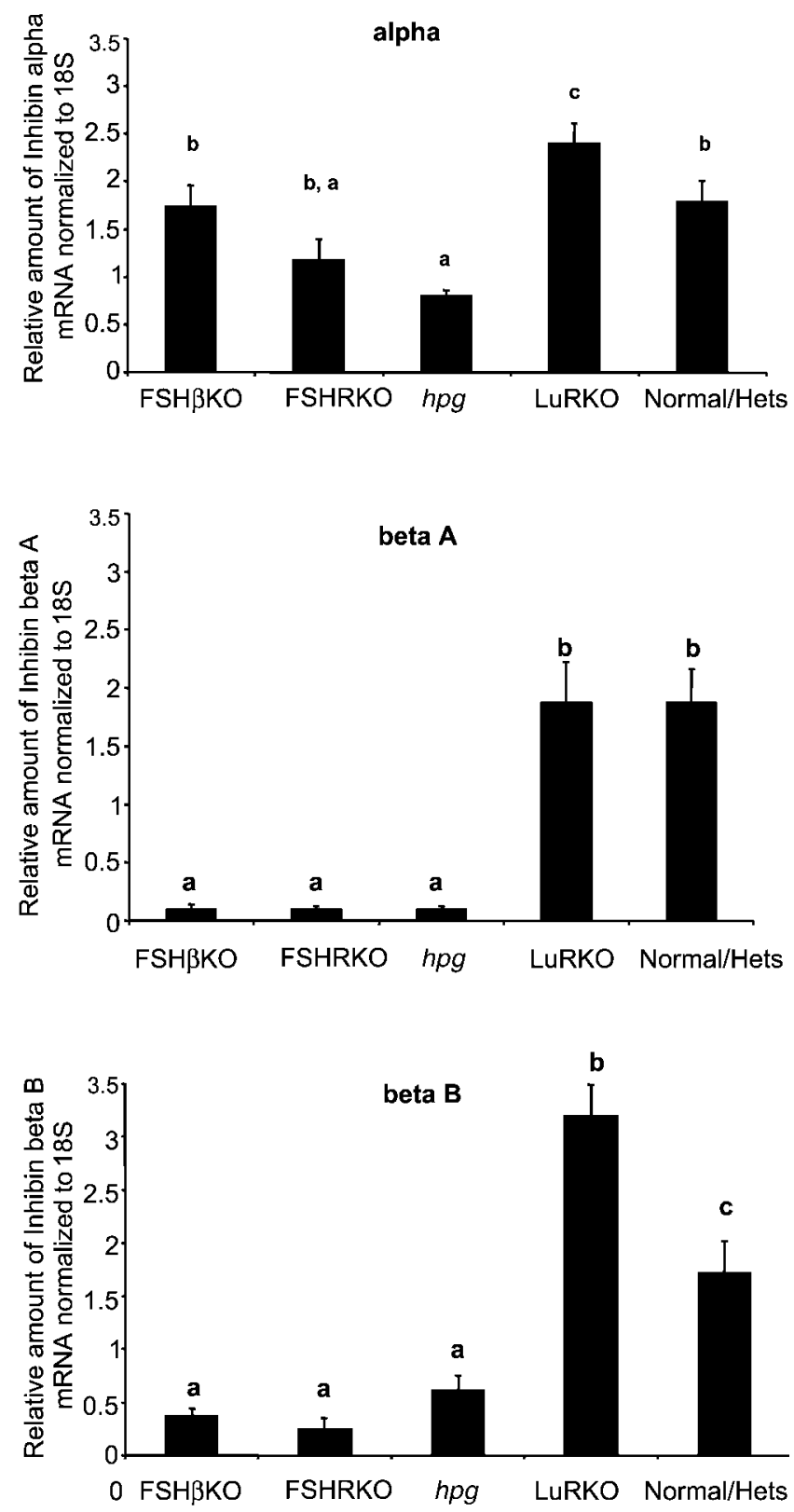

Figure 2 Real-time PCR amplification of inhibin subunits, inhibin alpha subunit, inhibin/activin beta $A$ subunit and inhibin/activin beta B subunit in 8-week-old mutant (FSH $\beta K O$, FSHRKO, $h p g$, LuRKO) and normal/heterozygous (Normal/Hets) female mice (normalized to 18S). Groups with different letter superscripts are significantly different. Results are expressed as means \pm S.E.M., $n=$ minimum of 4 in each group.

\section{Serum inhibin concentrations (Table 3)}

\section{Inhibin A}

Serum levels of inhibin A were below the level of detection of the assay in all the FSHßKO, FSHRKO and hpg females assayed. In contrast, inhibin A was detected in the serum of 5/8 LuRKO and 17/29 normal/heterozygous females. In the LuRKO females, serum levels of inhibin A ranged from 9.3 to $14.6 \mathrm{pg} / \mathrm{ml}$. In the normal/heterozygous group, levels ranged from 11.2 to $92.3 \mathrm{pg} / \mathrm{ml}$. The data were log transformed to correct for the differences in heterogeneity between the two groups and analysis of this data showed a significant difference $(P<0.05)$ between LuRKO and normal/heterozygous females.

In the normal/heterozygous group levels of inhibin A were related to the uterine weight, with a uterine weight of $>52 \mathrm{mg}$ always associated with a measurable level of inhibin A. This is likely to reflect variations in the stage of the estrous cycle, with a low uterine weight indicative of a diestrous phase with a lack of large estrogenic follicles.

\section{Inhibin B}

Serum levels of inhibin B were also below the level of detection of the assay in all FSH $\beta K O, F S H R K O$ and $h p g$ females. However, serum levels of inhibin B were detectable in all LuRKO females and in 25/29 normal/heterozygous females. Mean levels of inhibin B were significantly higher in the LuRKO females $(P<0.001)$ compared with the normal/heterozygous group.

\section{Ovarian inhibin immunohistochemistry (Fig. 4)}

\section{Inhibin $\alpha$}

Positive staining for inhibin $\alpha$ was seen in the granulosa cells of all females in this study but was not detected in theca or interstitial tissue nor in the corpora lutea of the normal or heterozygote females. Positive staining was detected in granulosa cells at all stages of follicular development.

\section{Inhibin $\beta A$}

Staining for inhibin $\beta A$ subunit could not be detected above background control sections in either mutant or normal/heterozygous ovaries.

\section{Inhibin $\beta B$}

Positive staining for inhibin $\beta B$ was only seen in ovaries from normal/heterozygous and LuRKO females and, as found for inhibin $\alpha$, was restricted to granulosa cells.

\section{Discussion}

Low levels of ovarian expression of inhibin $\beta A$ and $\beta B$ subunit genes were seen in the ovaries of 8-week-old FSH $\beta K O$, FSHRKO and hpg females. Lack of ovarian stimulation by $\mathrm{FSH}$ is a common feature of these three mutants. Therefore, FSH activation of its receptor on follicular granulosa cells appears to be required for transcription of these genes above basal levels. O'Shaughnessy and Gray (1995) reported significantly lower levels of inhibin $\beta A$ and $\beta B$ mRNA in hpg females relative to normal females up to postnatal day 15 .

Expression of inhibin $\alpha$ in the ovaries of $h p g$ and FSH mutant females was higher than that of the $\beta$ subunits 
A

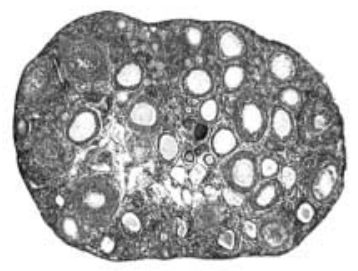

$h p g$

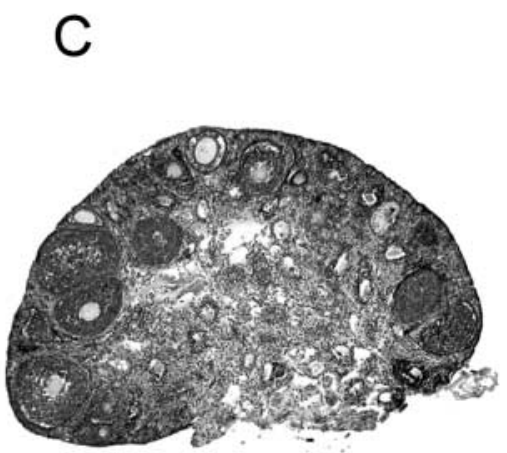

FSHBKO
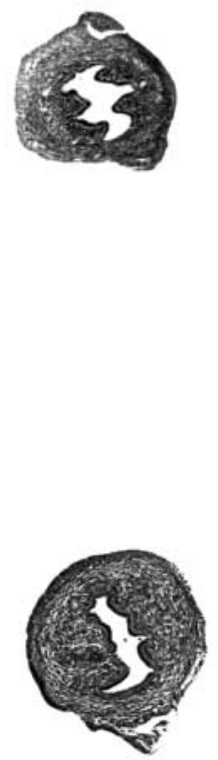

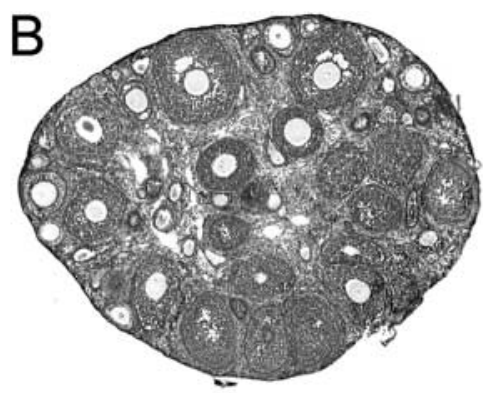

FSHRKO

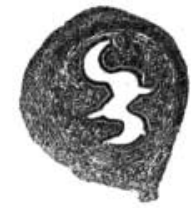

D
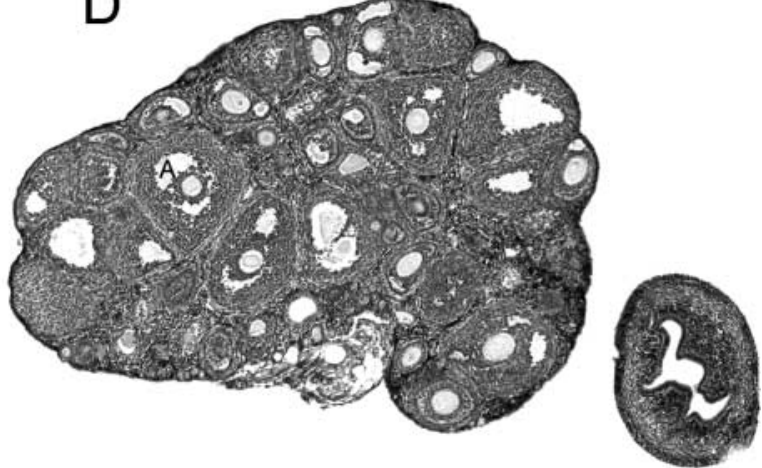

LuRKO
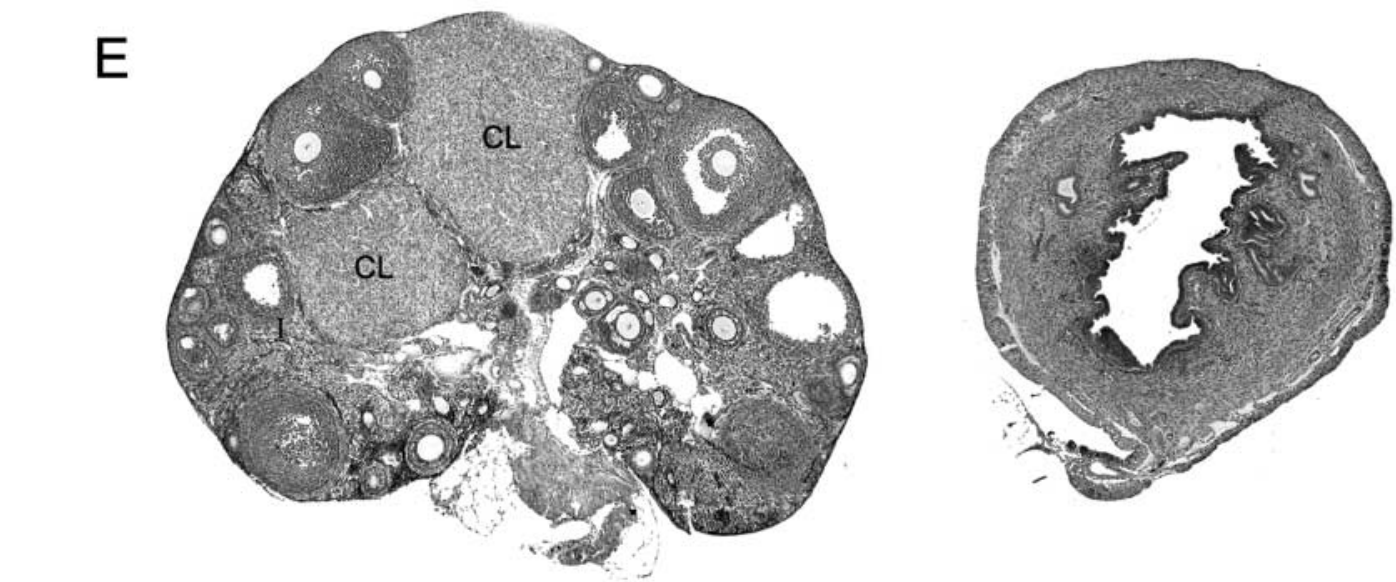

\section{$500 \mu \mathrm{m}$ \\ OVARY}

NORMAL

Figure 3 Sections through the ovaries and uteri of (A) $h p g$, (B) FSHRKO, (C) FSH $\beta K O$, (D) LuRKO and (E) normal female mice at 8 weeks of age. All ovaries were taken at the same magnification, as were uteri. Numerous small follicles can be seen throughout the ovaries from $h p g$, FSHRKO and FSH $\beta$ KO females, but no antral follicles or corpora lutea are present (A, B and C). In the LuRKO ovary (D) antral follicles can be seen but no pre-ovulatory follicles or corpora lutea are present. Note the small amount of interstial tissue between the antral follicles. Corpora lutea and follicles of all stages of development, including preovulatory, can be seen in the ovary from the normal female (E). CL, corpus luteum; I, interstitium; A, antrum. 
Table 2 Ovarian inhibin A and B content levels in mutant and normal/heterozygous 8 week-old female mice. Results are expressed as means \pm S.E.M. $(n)$.

\begin{tabular}{llc}
\hline Mouse & Inhibin A $(\mathrm{pg} / \mathrm{mg})$ & Inhibin B $(\mathrm{pg} / \mathrm{mg})$ \\
\hline FSHRKO & UD (7), $2.9(1)$ & UD $(2), 59.20 \pm 14(6)$ \\
FSHßKO & UD (7) & $59.0 \pm 15.4(7)$ \\
hpg & UD (10) & $87.0 \pm 23.3(10)$ \\
LuRKO & $61.7 \pm 10.4(5)$ & $794.5 \pm 86.1(5)$ \\
Normal/heterozygous & $100.0 \pm 20.3(30)$ & $292.2 \pm 34.1(30)$ \\
\hline
\end{tabular}

UD (undetectable) below the level of sensitivity of the assay: $<2.4 \mathrm{pg}$ per wet weight of ovary and $<17$ pg per wet weight of tissue for inhibin $A$ and $B$ respectively. There was no significant difference in levels of inhibin A between LuRKO and normal/heterozygous groups. There was no significant difference between levels of inhibin B in $\mathrm{FSH} \beta \mathrm{KO}$, FSHRKO and $h p g$ females. Levels of inhibin B were significantly higher in LuRKO females compared with the normal/heterozygous group $(P<0.001)$.

indicating that basal, constitutive transcription of this gene is less dependent on FSH. In support of this, O'Shaughnessy and Gray (1995) found no difference in ovarian mRNA levels of inhibin $\alpha$ between hpg and normal females from days 1 to 15 .

Synthesis of biologically active inhibin protein is dependent on dimerisation of $\alpha$ and $\beta$ subunits and the low levels of inhibin $\beta A$ subunit mRNA were reflected in undetectable levels of inhibin A protein within the ovary. In contrast, inhibin B protein was detectable within the ovaries of FSH $\beta K O, F S H R K O$ and $h p g$ females; therefore sufficient $\beta B$ protein must be formed to allow dimerization with the more abundant inhibin $\alpha$ subunit. In support of this finding both $\alpha$ and $\beta B$ but not $\beta A$ subunits have been detected in small follicles in the normal female rat, possibly representing follicles to be recruited in the following cycle (Meunier et al. 1988). However, ovarian content of inhibin $\beta \mathrm{B}$ in the $\mathrm{FSH} \beta K \mathrm{O}, \mathrm{FSHRKO}$ and $h p g$ females remained significantly lower than that measured in the ovaries of normal/heterozygous females and, in addition, inhibin B protein was not detected in the serum of any of the three mutants indicating that the amount of protein synthesized was not sufficient for the release of

Table 3 Serum inhibin A and B concentrations in mutant and normal/heterozygous 8-week-old female mice. Results are expressed as means \pm S.E.M. $(n)$.

\begin{tabular}{lcc}
\hline Mouse & Inhibin $\mathbf{A}(\mathrm{pg} / \mathrm{ml})$ & Inhibin $\mathbf{B}(\mathrm{pg} / \mathrm{ml})$ \\
\hline FSH $\beta K O$ & UD $(12)$ & UD $(12)$ \\
FSHRKO & UD (11) & UD (11) \\
hpg & UD (12) & UD (12) \\
LuRKO & UD (3), $11.7 \pm 1.0(5)$ & $166.1 \pm 0.9(8)$ \\
Normal/ & UD (12), $31.6 \pm 6.0(17)$ & UD (4), $104.0 \pm 6.7(25)$ \\
heterozygous & &
\end{tabular}

UD (undetectable) below the level of sensitivity of the assay: $<7.8 \mathrm{pg} / \mathrm{ml}$ and $<50 \mathrm{pg} / \mathrm{ml}$ for inhibin $A$ and inhibin $B$ respectively. Levels of inhibin A were significantly higher $(P<0.05)$ in the normal/heterozygous females compared with the LuRKO females (data log transformed). Levels of inhibin B were significantly higher $(P<0.001)$ in the LuRKO females compared with the normal/heterozygous group. appreciable amounts into the bloodstream. In vitro studies in the rat found low levels of inhibin mRNAs in unstimulated granulosa cells in culture (Turner et al. 1989).

The early stages of follicular development have been shown to be gonadotropin independent (Kendall et al. 1991, 1995) and the FSH $\beta K O$, FSHRKO and hpg females reflect this in that all follicular stages up to pre-antral can be seen but antral and mature follicles have not been detected in these ovaries. Therefore, ovaries in which immature follicles predominate appear to produce very little biologically active inhibin. In support of this we have only been able to detect inhibin $\alpha$ but not $\beta B$ or $\beta$ A protein by immunohistochemistry in the ovaries of the FSH $\beta K O$, FSHRKO and hpg females.

In the LuRKO female significantly higher levels of ovarian expression of all three inhibin genes were seen compared with the FSH $\beta K O$, FSHRKO and hpg females. In this mutant, ovarian follicular development progresses beyond that seen in the FSH mutant and hpg females, reflecting the ability of this ovary to respond to the high levels of FSH in the circulation (Zhang et al. 2001). Therefore, granulosa cell stimulation by FSH allows significant upregulation of transcription of all three inhibin genes above basal levels. Rat granulosa cells in culture respond to FSH with a marked rise in mRNA levels of all three inhibin genes (Turner et al. 1989) and in the normal female rat coordinated expression of inhibins $A$ and $B$ was seen in follicles of the ovulatory pool (Meunier et al. 1988, Woodruff et al. 1988).

Ovarian expression of inhibin $\beta A$ subunit mRNA in the LuRKO females was similar to that seen in the ovaries of normal/heterozygous females, and ovarian content of inhibin A protein did not differ significantly between the two groups. However, the range of inhibin A levels in the serum of the LuRKO females was much lower than that seen in the normal/heterozygous females. In the normal female rat $\beta A$ subunit mRNA has been reported to increase progressively from newly recruited to preovulatory follicles, with the highest levels in large tertiary follicles in which granulosa cells have acquired LH receptors (Meunier et al. 1988, Arai et al. 2002). Serum inhibin levels in rats follow a pattern consistent with this during the estrous cycle (Fahy et al. 1995, Woodruff et al. 1996). This stage of follicular development is not reached in the LuRKO female and the levels of inhibin $\beta A$ mRNA and inhibin $A$ protein in the individual pre-antral and antral follicles of the LuRKO female are likely to be lower than those attained in pre-ovulatory follicles.

In contrast, expression of both inhibin $\alpha$ and inhibin $\beta B$ subunit genes was significantly higher in ovaries from LuRKO females compared with that seen in normal/heterozygous ovaries and this was reflected in significantly higher ovarian and serum levels of inhibin B protein in the LuRKO females.

In the normal female, FSH output from the pituitary is regulated, in part, by ovarian estrogen (Richards 1980). since serum $\mathrm{FSH}$ and $\mathrm{LH}$ are significantly elevated in 

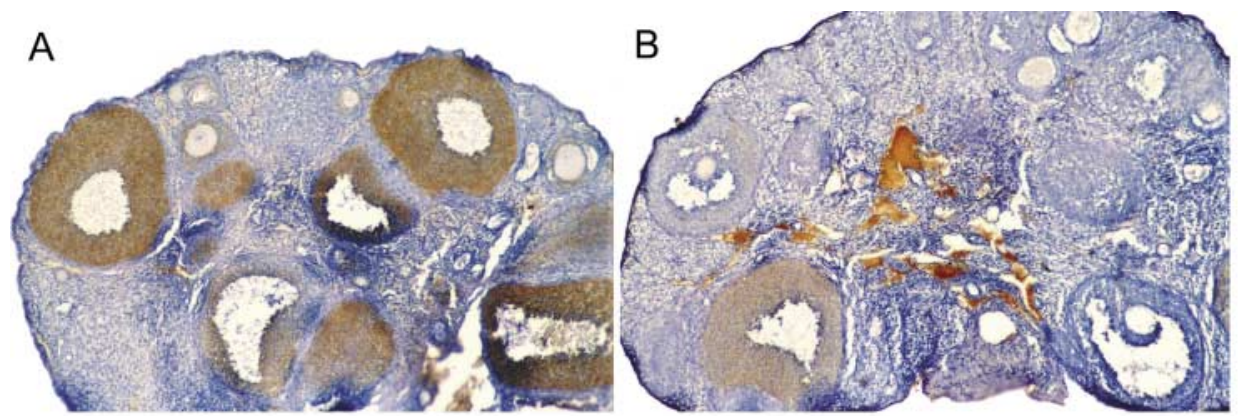

NORMAL
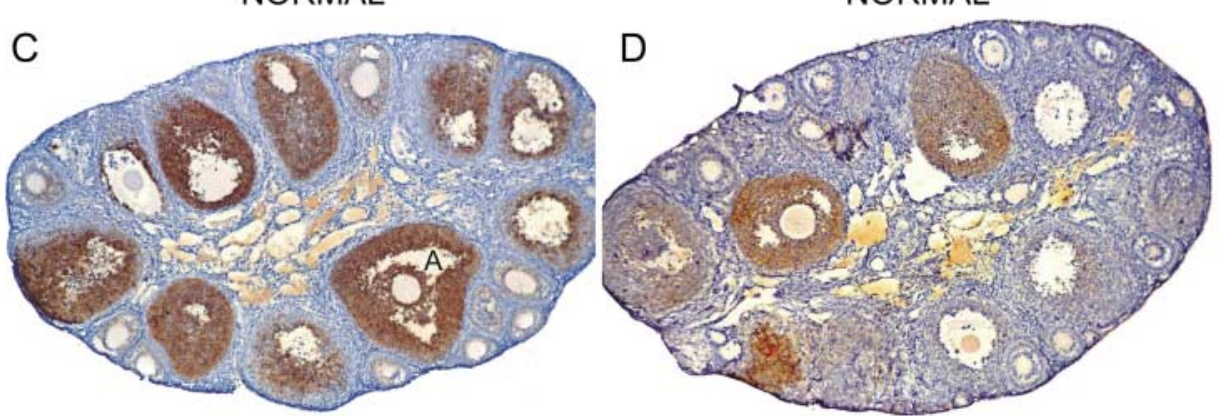

LuRKO
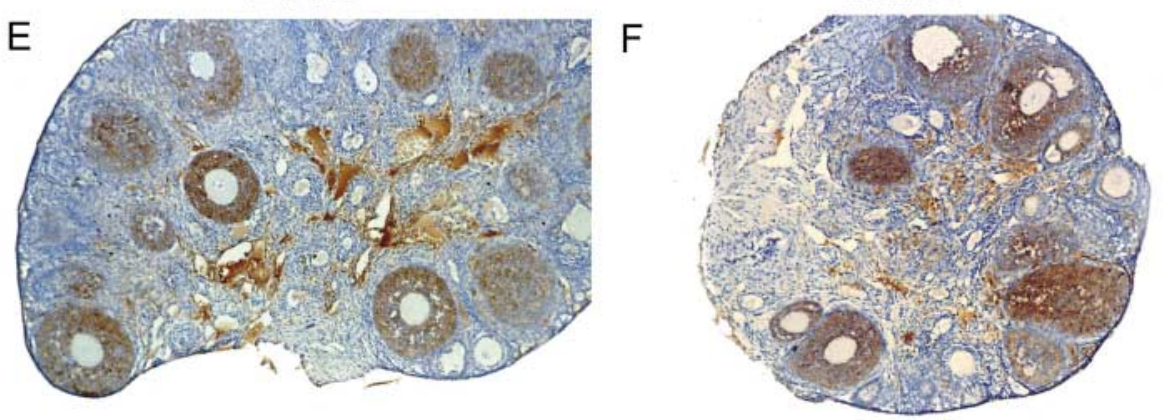

FSH $\beta$ KO

G

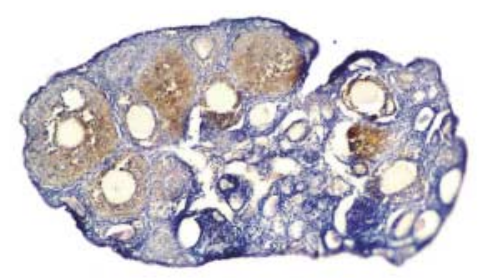

hpg

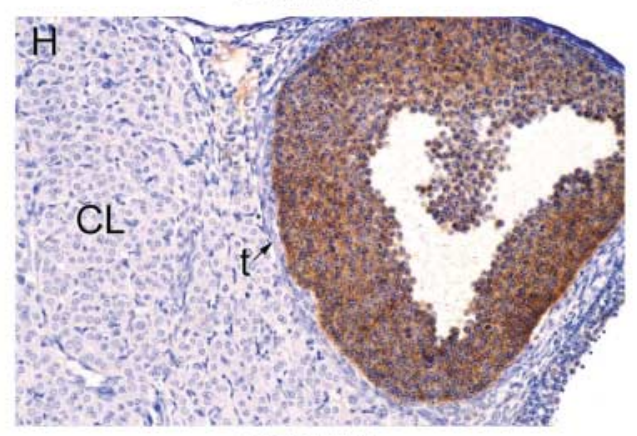

NORMAL

\section{$300 \mu \mathrm{m}$}

$150 \mu \mathrm{m}$

Figure 4 Immunohistochemical staining for inhibin $\alpha(A, C, E, F, G$ and $H)$ and $\beta B$ subunits ( $B$ and $D)$. Positive staining for both subunits is shown as brown against a blue background stain (hematoxylin). Scale bars represent $300 \mu \mathrm{m}$ (A, B, C, D, E, F and G) and $150 \mu \mathrm{m}(\mathrm{H})$. Staining for inhibin $\alpha$ subunit is seen in granulosa cells of all sized follicles in the (A) normal, (C) LuRKO, (E) FSH $\beta K O$, (F) FSHRKO and (G) hpg ovaries. Staining for inhibin $\beta B$ subunit is seen in granulosa cells of normal and LuRKO females (B and D); however no staining for inhibin $\beta B$ was detected in FSH $\beta$ KO, FSHRKO and hpg ovaries (results not shown). At higher magnification $(\mathrm{H})$, note restriction of positive staining for inhibin $\alpha$ to the granulosa cells. CL, corpus luteum; A, antrum; $\mathrm{t}$, theca cell layer. 
LuRKO females (Zhang et al. 2001) and there is no evidence of biologically active estrogen in the circulation of LuRKO females as evidenced by the thin, atropic uteri, there is little or no estrogen regulation of either $\mathrm{FSH}$ or $\mathrm{LH}$ output from the pituitary. In the LuRKO female the high levels of FSH result in continuous follicular stimulation which cannot proceed to ovulation due to the inability of this ovary to respond to $\mathrm{LH}$. As a result antral follicles occupy the majority of the ovary in the LuRKO female, and granulosa cells at a stage highly responsive to $\mathrm{FSH}$ constitute the predominant cell type in this ovary. In contrast, ovaries from normal/heterozygous females contain all stages of follicular development including mature follicles and also corpora lutea. Antral follicles and granulosa cells form a much smaller proportion of the overall tissue at any time. This difference may well account for the higher levels of inhibin $\alpha$ and $\beta B$ subunit mRNAs and inhibin B found in the LuRKO ovaries. Turner et al. (1989) showed that rat granulosa cells in culture responded not only to $\mathrm{FSH}$ but also to exogenous estrogen with an increase in mRNA levels of inhibin $\alpha$ and inhibin $\beta B$ but not inhibin $\beta$ A. The response to estrogen alone was several fold lower than that seen with FSH. Athough there is no evidence of estrogen in the circulation of LuRKO female mice, Zhang et al. (2001) reported measurable levels of estrogen in the ovaries of this mutant, although they were only $10 \%$ of those measured in wild-type mice. Intraovarian estrogen in the LuRKO female could therefore further increase transcription of the inhibin $\alpha$ and inhibin $\beta B$ genes and contribute to the higher levels of mRNA and protein levels of inhibin $B$ relative to levels in nor$\mathrm{mal} /$ heterozygous mice.

Since inhibin $\beta B$, but not $\beta A$, is increased in the ovaries of the LuRKO females, there is likely to be differential regulation of these peptides within the follicle, with increased production of inhibin $\beta \mathrm{A}$ occurring as $\mathrm{LH}$ augments the declining FSH levels in the circulation in the preovulatory phase (Woodruff et al. 1996). Our data indicate that increased levels of FSH can increase production of inhibin $B$ in granulosa cells but that the high levels of $\beta A$ reported in the late follicular phase may require $\mathrm{LH}$ stimulation in addition.

In the rat, inhibin $\alpha$ mRNA has been detected in thecal and interstitial tissue and in cells of early corpora lutea (Hsu et al. 1995, Hsueh et al. 1987). In contrast, Woodruff et al. (1996) found no evidence of inhibin subunits in rat corpora lutea. In the ovaries of all females in this study we find unequivocal immunohistochemical staining for inhibin $\alpha$ only in the granulosa cells. Staining for inhibin $\beta B$ was only seen in ovaries from normal/heterozygous and LuRKO females and was also restricted to granulosa cells. Staining for $\beta$ A subunit could not be detected above background control sections. Interestingly, in the LuRKO ovary, where the highest levels of inhibin mRNAs and protein were detected, the $\mathrm{LH}$-dependent stromal/interstitial compartment was minimal. Thus in the mouse we have no evidence for production of inhibins outwith the granulosa compartment. In a recent study in the sheep using in situ hybridization, expression of all inhibin subunits was also confined to the granulosa cells (Campbell \& Baird 2001).

In summary, our findings in hpg, FSH $\beta K O$, FSHRKO and LuRKO female mice provide further evidence for FSH-dependent ovarian expression of all three inhibin subunit genes above basal levels. Paracrine actions of estrogen within the ovarian follicle appear to augment $\mathrm{FSH}$-induced transcription of the inhibin genes but this study has shown that the major determinant of inhibin B synthesis within the ovary at any one time is the mass of FSH-responsive granulosa tissue, whereas additional stimulation by LH may be required for increased inhibin A synthesis. Synthesis of the inhibin subunits appears to be restricted to granulosa cells throughout the estrous cycle in the mouse and future work using laser capture microdissection of individual ovarian compartments in mutant and normal mice throughout development will allow confirmation of this together with identification of time of onset of inhibin synthesis.

\section{Acknowledgements}

This work was supported by the Wellcome Trust and the University of Oxford.

\section{References}

Abel MH, Wootton AN, Wilkins V, Huhtaniemi I, Knight PG \& Charlton HM 2000 The effect of a null mutation in the folliclestimulating hormone receptor gene on mouse reproduction. Endocrinology 141 1795-1803.

Ackland JF, D'Agostino J, Ringstrom SJ, Hostetler JP, Mann BG \& Schwartz NB 1990 Circulating radioimmunoassayable inhibin during periods of transient follicle-stimulating hormone rise: secondary surge and unilateral ovariectomy. Biology of Reproduction 43 347-352.

Arai KY, Ohshima K, Watanabe G, Arai K, Uehara K \& Taya K 2002 Dynamics of messenger RNAs encoding inhibin/activin subunits and follistatin in the ovary during the rat estrous cycle. Biology of Reproduction 66 1119-1126.

Bustin SA 2002 Quantification of mRNA using real-time reverse transcription PCR (RT-PCR): trends and problems. Journal of Molecular Endocrinology 29 23-39.

Campbell BK \& Baird DT 2001 Inhibin A is a follicle stimulating hormone-responsive marker of granulosa cell differentiation, which has both autocrine and paracrine actions in sheep. Journal of Endocrinology $169333-345$.

Cattanach BM, Iddon CA, Charlton HM, Chiappa SA \& Fink G 1977 Gonadotrophin-releasing hormone deficiency in a mutant mouse with hypogonadism. Nature $269338-340$.

D'Agostino J, Woodruff TK, Mayo KE \& Schwartz NB 1989 Unilateral ovariectomy increases inhibin messenger ribonucleic acid levels in newly recruited follicles. Endocrinology 124 310-317.

De Jong FH \& Sharpe RM 1976 Evidence for inhibin-like activity in bovine follicular fluid. Nature $26371-72$.

Fahy PA, Wilson CA, Beard AJ, Groome NP \& Knight PG 1995 Changes in inhibin-A (alpha-beta A dimer) and total alpha inhibin in the peripheral circulation and ovaries of rats after gonadotrophin-induced follicular development and during the normal oestrous cycle. Journal of Endocrinology 147 271-283.

Findlay JK 1994 Peripheral and local regulators of folliculogenesis. Reproduction, Fertility and Development 6 127-139. 
Forage RG, Ring JM, Brown RW, McInerney BV, Cobon GS, Gregson RP, Robertson DM, Morgan FJ, Hearn MT \& Findlay JK 1986 Cloning and sequence analysis of cDNA species coding for the two subunits of inhibin from bovine follicular fluid. PNAS $\mathbf{8 3}$ 3091-3095.

Groome NP, Illingworth PJ, O'Brien M, Pai R, Rodger FE, Mather JP \& McNeilly AS 1996 Measurement of dimeric inhibin B throughout the human menstrual cycle. Journal of Clinical Endocrinology and Metabolism 81 1401-1405.

Hillier SG, Yong EL, Illingworth PJ, Baird DT, Schwall RH \& Mason AJ 1991 Effect of recombinant inhibin on androgen synthesis in cultured human thecal cells. Molecular and Cellular Endocrinology $75 \mathrm{R} 1-\mathrm{R} 6$.

Hsu SY, Lai RJ, Nanuel D \& Hsueh AJ 1995 Different 5'-flanking regions of the inhibin-alpha gene target transgenes to the gonad and adrenal in an age-dependent manner in transgenic mice. Endocrinology 136 5577-5586.

Hsueh AJ, Dahl KD, Vaughan J, Tucker E, Rivier J, Bardin CW \& Vale W 1987 Heterodimers and homodimers of inhibin subunits have different paracrine action in the modulation of luteinizing hormone-stimulated androgen biosynthesis. PNAS 84 5082-5086.

Kendall SK, Saunders TL, Jin L, Lloyd RV, Glode LM, Nett TM, Keri RA, Nilson JH \& Camper SA 1991 Targeted ablation of pituitary gonadotropes in transgenic mice. Molecular Endocrinology $\mathbf{5}$ 2025-2036.

Kendall SK, Samuelson LC, Saunders TL, Wood RI \& Camper SA 1995 Targeted disruption of the pituitary glycoprotein hormone alpha-subunit produces hypogonadal and hypothyroid mice. Genes and Development 9 2007-2019.

Kumar TR, Wang Y, Lu N \& Matzuk MM 1997 Follicle stimulating hormone is required for ovarian follicle maturation but not male fertility. Nature Genetics 15 201-204.

Lang J 1991 Assay for deletion in GnRH (hpg) locus using PCR. Mouse Genome 89857.

Ling N, Ying SY, Ueno N, Esch F, Denoroy L \& Guillemin R 1985 Isolation and partial characterization of a Mw 32000 protein with inhibin activity from porcine follicular fluid. PNAS 82 7217-7221.

Mason AJ, Hayflick JS, Ling N, Esch F, Ueno N, Ying SY, Guillemin R, Niall H \& Seeburg PH 1985 Complementary DNA sequences of ovarian follicular fluid inhibin show precursor structure and homology with transforming growth factor-beta. Nature 318 659-663.

Mason AJ, Hayflick JS, Zoeller RT, Young WS 3rd, Phillips HS, Nikolics K \& Seeburg PH 1986 A deletion truncating the gonadotropin-releasing hormone gene is responsible for hypogonadism in the hpg mouse. Science 234 1366-1371.

Mayo KE, Cerelli GM, Spiess J, Rivier J, Rosenfeld MG, Evans RM \& Vale W 1986 Inhibin A-subunit cDNAs from porcine ovary and human placenta. PNAS 83 5849-5853

Meunier H, Cajander SB, Roberts VJ, Rivier C, Sawchenko PE, Hsueh AJ \& Vale W 1988 Rapid changes in the expression of inhibin alpha-, beta A-, and beta B-subunits in ovarian cell types during the rat estrous cycle. Molecular Endocrinology 2 $1352-1363$.
Muttukrishna S, Fowler PA, Groome NP, Mitchell GG, Robertson WR \& Knight PG 1994 Serum concentrations of dimeric inhibin during the spontaneous human menstrual cycle and after treatment with exogenous gonadotrophin. Human Reproduction 9 1634-1642.

O'Shaughnessy PJ \& Gray SA 1995 Gonadotropin-dependent and gonadotropin-independent development of inhibin subunit messenger ribonucleic acid levels in the mouse ovary. Endocrinology $1362060-2065$

Richards JS 1980 Maturation of ovarian follicles: actions and interactions of pituitary and ovarian hormones on follicular cell differentiation. Physiology Reviews 60 51-89.

Rivier C, Schwall R, Mason A, Burton L \& Vale W 1991 Effect of recombinant inhibin on gonadotropin secretion during proestrus and estrus in the rat. Endocrinology 128 2223-2228.

Robertson DM, Foulds LM, Leversha L, Morgan FJ, Hearn MT, Burger HG, Wettenhall RE \& de Kretser DM 1985 Isolation of inhibin from bovine follicular fluid. Biochemistry and Biophysics Research Communications 126 220-226.

Schwartz NB \& Channing CP 1977 Evidence for ovarian 'inhibin': suppression of the secondary rise in serum follicle stimulating hormone levels in proestrous rats by injection of porcine follicular fluid. PNAS 74 5721-5724.

Turner IM, Saunders PT, Shimasaki S \& Hillier SG 1989 Regulation of inhibin subunit gene expression by FSH and estradiol in cultured rat granulosa cells. Endocrinology 125 2790-2792.

Woodruff TK, D'Agostino J, Schwartz NB \& Mayo KE 1988 Dynamic changes in inhibin messenger RNAs in rat ovarian follicles during the reproductive cycle. Science 239 1296-1299.

Woodruff TK, Krummen LA, Lyon RJ, Stocks DL \& Mather JP 1993 Recombinant human inhibin A and recombinant human activin A regulate pituitary and ovarian function in the adult female rat. Endocrinology 132 2332-2241.

Woodruff TK, Besecke LM, Groome N, Draper LB, Schwartz NB \& Weiss J 1996 Inhibin A and inhibin B are inversely correlated to follicle-stimulating hormone, yet are discordant during the follicular phase of the rat estrous cycle, and inhibin $A$ is expressed in a sexually dimorphic manner. Endocrinology 137 $5463-5467$.

Wrathall JH \& Knight PG 1995 Effects of inhibin-related peptides and oestradiol on androstenedione and progesterone secretion by bovine theca cells in vitro. Journal of Endocrinology 145 $491-500$.

Zhang FP, Poutanen M, Wilbertz J \& Huhtaniemi I 2001 Normal prenatal but arrested postnatal sexual development of luteinizing hormone receptor knockout (LuRKO) mice. Molecular Endocrinology $15172-183$.

Received 16 January 2004

First decision 26 March 2004

Accepted 22 April 2004 